\title{
治療薬剤と咽喉頭異常感の消失率
}

\author{
山際 幹和・坂倉 康夫・原田 輝彦 \\ 久保 将彦・福生 治城・福喜多啓三
}

\section{Rates of Complete Cure of Abnormal Sensation in the Throat with Various Medicines}

\author{
Mikikazu Yamagiwa, Yasuo Sakakura, Teruhiko Harada, \\ Masahiko Kubo, Haruki Fukuo and Keizo Fukukita \\ (Mie University)
}

During the past 10 years we have treated a total of 1,132 patients with abnormal sensation in the throat with 11 active and 2 inactive oral medicines for two weeks or psychotherapy. The complete cure rate (CCR) was determined 1, 2 and 3 weeks after the start of treatment.

Three Kampo medicines (hange-koboku-to, saiko-ka-ryukotsu-borei-to and saibokuto), which are supposed to be mainly effective for psychosomatic disorders, and sulpiride, an antidepressant and considered to be effective for other central nervous system disorders, gave the best results: their CCR's were $13 \sim 18 \%$ at 1 week, $14 \sim 24 \%$ at 2 and $18 \sim 32 \%$ at 3 weeks.

The CCR's for two (oxazolam and diazepam) of the three minor tranquilizers were high at 1 and 2 weeks $(19 \sim 30 \%)$, but not at 3 weeks $(13 \sim 14 \%)$. Symptoms recurred soon after the cessation of the therapy with these two medicines. The GCR of the other minor tranquilizer, alprazolam, was not high (8\%) at 1 week, but it rose (13\%) at 2 weeks and stayed at $13 \%$ at 3 weeks.

On the other hand, the administration of other medicines [dosulepin hydrochloride (pure anti-depressant), hormone complex, lysozyme chloride (anti-inflammatory agent) and tiaprofenic acid (anti-inflammatory agent)] could not produce any better CCR's (3 7\%) at 1 week than the two kinds of inactive medicines $(3 \sim 4 \%)$ or psychotherapy without any drugs. At 2 and 3 weeks the CCR's for the former 4 medicines $(7 \sim 16 \%)$ were slightly, but not significantly, higher than those $(4 \sim 16 \%)$ for the inactive medicines or psychological treatment.

Key words: abnormal sensation in the throat, treatment with active and inactive medicines, complete cure rate 


\section{はじめに}

咽喉頭異常感を引き起こす要因としては，局 所的, 全身的あるいは精神的要因がとりあげら れ，今日までにそれに応じた種々の治療が試み られている1) 3).

我々は, 最近 10 年間, 漢方製剤, 精神神経用 薬，消炎・鎮痛・解熱剂あるいは代謝性ホルモ ン製剤などを汇湆無作為的に単独あるいは併用 投与して咽喉頭異常感症患者を治療し，一定の 効果判定基準を設けてそれらの薬効を評価して きた4)〜19).

我々が用いている効果判定方法の概念は, 我 我の身近にあるものの中では, 日本癌治療学会 固形がん化学療法直接効果判定基準20) に極め て近い。つまり，治療前に個々の患者の有して いた咽喉頭異常感の強さ (程度や頻度)を評価す ることなく一律 10 点とし，それが消失した状態 を 0 点とした場合, 評価時点ではそれが何点で あるかを患者自身に評価させ，その点数を解析 資料とする方法である。そして, 我々は, 評価 時点での点数が 5 以下 (日本癌治療学会固形が 几化学療法直接効果判定基準20) では partial response [PR]に相当)を広義の有効とした。

咽喉頭異常感症の治癒を問題とした場合, 治 癒につながる状態として，一定期間咽喉頭異常 感が消失している状態, つまり, 癌治療に括け る complete response (CR) の状態が得られる ことが必須である。

そこで，ここでは，我々が今日までに収集し た延べ1132症例のデータを解析資料として，偽 薬を含めて単一の薬剤を用いて本症を治療した 際や，あるいは無投薬治療を行った際に，どの 程度で咽喉頭異常感消失 ( 0 点) 状態, つまり, $\mathrm{CR}$ の状態が得られるかを検討した.

\section{治療方法の原則と評価時期}

我々が行っている咽喉頭異常感を訴兄る患者 の診断治療の手順の詳細は既に報告4) 19) して あるので繰り返しは避けるが，我々は当初より， 症状の原因が悪性腫瘍である可能性は殆ど無い

ことを十分強調することを大原則としたらえで，
通常は薬剂を 2 週間投与し，投薬後 1,2 週目 および投薬終了後 1 週を経た 3 週目にその効果 を評価している。投薬期間を 2 週間としたこと は, 薬剤の如何に拘らずその間に何らかの効果 が得られるものと考えたことと，投薬終了後 1 週目にも評価したことは，薬効の持続性を検討 する目的で行った．な拉，後で述べる無投薬治 療例とは，以上の大原則に従うも薬剂を投与せ ずに診療を行った例である。

\section{評価方法}

咽喉頭異常感の強さを他覚的に的確に評価す ることは殆ど不可能であり, 我々は冒頭で述べ たように，治療開始前の異常感の強さを一律 10 点, 異常感のない状態を 0 点とした場合, 各評 価時点の異常感は何点であるかを患者自身に採 点してもらい，それを解析資料としている。 こ こでいう0 点とは, 完全に異常感が消失した状 態であり，患者にとっては容易に採点でき，ま た，医師にとっても効果を把握するら党で，極 めて明快な状態である。

今回は，各種薬羭による治療や無投薬治療を 行った場合, 投薬後 $1,2,3$ 週目の異常感消失 率はどらであったかを検討した。

\section{検討薬剤ならびに方法}

単独効果を検討した薬剂とそれらの対象患者 を性別にみた例数は表 1 に示したごとくである. それぞれの治療後 1，2，3 週目に打都咽喉頭 異常感消失率，つまり0点になった患者の比率 を算出した。

対象患者の背景が必ずしも等しくないので, 厳密にこれらの成績を推計学的手法を用いて比 較することはできないため，ここでは消失率の 表示にとどめる.

\section{結果ならびに考察}

\section{1. 無投薬 (表 1)}

無投薬例での 1,2 および 3 週目の咽喉頭異 常感消失率は，それぞれ $4 \% ， 4 \% ， 6 \%$ ぞあ った。後で述べるように，この率は薬剤を用い て本症を治療した際の成績に比べると極めて低 い. 
咽喉頭異常感は無投薬治療であれ，説得を十 分行えばかなりの率で治癒すると考兄られがち であるが，必ずしもそうとは言えず，この成績 は，無投薬治療で咽喉頭異常感を軽快させるこ とはできても治瘉させることは容易ではないこ とを示唆している.

\section{2. 漢方製剤エキス顆粒 (表 1)}

検討した半夏厚朴湯，柴胡加竜骨牡蠣湯およ び柴朴湯の 3 剤(4)5)14) の場合ともに $1,2,3$ 週 目のどの時点でも，消失率は無投薬あるいは咽 喉頭異常感江効果的とは考光難く偽薬の意味で 用いた安中散エキス顆粒や乳糖錠を投与した際 のそれらに比べ明らかに高く，1，2 および 3 週目の咽喉頭異常感消失率は，それぞれ $13 \sim 15$ $\% ， 14 〜 23 \% ， 18 〜 32 \%$ であった。

漢方製剤を用いた治療の場合，概して効果の 出現までに時間を要し，遅効的であるとされて いるが，投薬後 1 週間の時点でも，顕著な効果 の出現する例が少なくないことが示唆された.

半夏厚朴湯投与例では，東洋医学的にみて高
い効果が期待できる女性例のみを対象として投 与したことも一因かと思われるが，消失率は全 ての時点で 3 剂のうちで最も高く，特に，投薬 終了後 1 週を経た 3 週目のそれが $32 \%$ に達した ことが目立った。

$$
\text { 3. マイイナートランキライザー(表 1) }
$$

オキサゾラム ${ }^{6)}$ とジアゼパム ${ }^{18)}$ 投与例ではと もに 1,2 週目の咽喉頭異常感消失率は等しく, それぞれ30\%，19\%と高率であった。他方，ア ルプラン゙ラム投与例13) のそれらは $8 \%$ と $13 \%$ であり，いわゆる立ち上がりは急峻ではなかっ た。しかしながら，前 2 者で投薬終了後の再燃 が生じたこともあり，3剤ともに投薬終了後 1 週目の 3 週目にはそれが13〜14\%になり，それ ぞれの間での差がなくなった。

確かに，投薬期間中のマイナートランキライ ザーの効果は著しいが，投薬終了後の再燃は問 題であり，治療上工夫が必要である。その意味 で，我々は消炎・鎮痛・解熱剂や漢方製剂を併 用投与した ${ }^{15) ~ 19) 。 ~}$ 。いずれの場合でも，投薬終

表 1 治療薬剤別にみた咽喉頭異常感の消失率

\begin{tabular}{|c|c|c|c|c|c|}
\hline \multirow{2}{*}{ 薬剤および 1 日使用量 } & \multicolumn{2}{|c|}{ 対象例 } & \multicolumn{3}{|c|}{ 消失率 $(\%)$} \\
\hline & 男 & 女 & 1 週目 & 2 週目 & 3 週目 \\
\hline 半夏厚朴湯エキス顆粒 $7.5 \mathrm{~g}$ & 0 & 96 & 15 & 23 & 32 \\
\hline 柴胡加竜骨牡蠣湯エキス顆粒 $7.5 \mathrm{~g}$ & 89 & 50 & 13 & 14 & 18 \\
\hline 柴朴湯エキス顆粒 $7.5 \mathrm{~g}$ & 38 & 62 & 14 & 18 & 22 \\
\hline オキサゾラム $60 \mathrm{mg}$ & 15 & 22 & 30 & 30 & 14 \\
\hline ジアゼパム $4 \mathrm{mg}$ & 26 & 37 & 19 & 19 & 13 \\
\hline アルプラゾラム $2 \mathrm{mg}$ & 28 & 44 & 8 & 13 & 13 \\
\hline スルピライド $300 \mathrm{mg}$ & 50 & 53 & 18 & 24 & 24 \\
\hline 塩酸ドスレピン 25〜 $50 \mathrm{mg}$ & 27 & 32 & 3 & 7 & 10 \\
\hline 代謝性ホルモン剤 3 錠 & 0 & 49 & 4 & 12 & 16 \\
\hline 塩化リゾチーム 270〜300 mg & 35 & 57 & 4 & 12 & 12 \\
\hline チアプロフェン酸 $600 \mathrm{mg}$ & 48 & 51 & 7 & 10 & 15 \\
\hline 安中散エキス顆粒 $7.5 \mathrm{~g}$ & 22 & 28 & 4 & 6 & 8 \\
\hline 乳糖錠 3 錠 & 35 & 38 & 3 & 10 & 16 \\
\hline 無投薬 & 34 & 66 & 4 & 4 & 6 \\
\hline
\end{tabular}

注)各薬剤は 2 週間投与 
了後の早期再燃を阻止すると考えられたが， 、 イナートランキライザーが漢方製剤の効果を打 ら消す可能性も示唆されたので17)，両者の併用 投薬に際してはその点を注意する必要がある。

4. らつ状態治療薬 (表 1)

スルピライド8) と塩酸ドスレピン11) は抗うつ 作用を有するとされている. スルピライド投与 例の場合の消失率は 1 週目から高く $(18 \%)$, 投 薬終了後のそれも $24 \%$ で再然は認められなかっ た，それに対して，塩酸ドスレピンでの消失率 はいずれの週でも低率 $(3,7,10 \%)$ で殆ど無 投薬例や偽薬使用例のそれらと変わりがなかっ た。

これらの 2 剂は，らつ状態に対する効果につ いてみれば，著しい差は無いものと予測される が，咽喉頭異常感に対する効果はかなり異なっ ている，すなわち，スルピライドの場合，無作 為的に投与しても良好な効果が得られる. それ に対して, 塩酸ドスレピンの場合, 抑うつ状態 の顕著な例での効果が明らかに高く ${ }^{11)}$ ，投薬に 際して患者の心身医学的な評価を行うと一層効 果的な治療が可能であると思われる.

我々は，自験例より，スルピライドは心的要 因の関与した種々の耳鼻咽喉科疾患に奏功する ことから，抗らつ作用の他にもいくつかの未知 の作用を秘めている可能性があると考えている.

5. 代謝性ホルモン剂(表 1)

更年期女性に用いられることが多く，ホルモ ンバランスを調えるとされる代謝性ホルモン剂 の場合, 1 週目の消失率は極めて低率 $(4 \%)$ で あったが， 2 週目以後それが上昇し，投薬終了 後のその率 $(16 \%)$ が最高になった。この成績は, 同様に女性例のみを対象として投薬した半夏厚 朴湯エキス顆粒による治療成績と比べるとかな り劣っている.

ただ，この薬剤は，その作用機序より長期投 薬によりはじめて十分な効果を発揮する可能性 もあり, 効果判定の時期が早すぎることも否め ない.
6. 消炎・鎮痛・解熱剤(表 1 )

塩化リゾチーム10) は消炎, チアプロフェン 酸 ${ }^{12)}$ は消炎・鎮痛・解熱作用を持つとされて いる.ともに, 1 週目の消失率は高くはなかっ たが $(4 ， 7 \%) ， 2$ 週目でその率が上昇し(12, $10 \%)$, 効果は持続的 $(12,15 \%)$ であった.

ただし，これらの成績は, 我々が偽薬の意味 で投与した乳糖錠による治療成績と殆ど差がな く, これらの有效性の点に関してはさらに検討 の余地がある.

実地臨床では，消炎・鎮痛・解熱剤とマイナ ートランキライザーを併用投与すると 15)16)18119), 1 週目より高い消失率が得られるのみならず, 投薬終了後の消失率もさらに高い状態で維持さ れるので $(17 \sim 24 \%)$, 両者の併用は有意義であ ると考光る。

\section{7 . 偽薬(表 1 )}

安中散エキス顆粒7) と乳糖錠 ${ }^{13)}$ は偽薬の意味 で使用した。安中散エキス顆粒投与例では, 各 週の消失率 $(4,6,8 \%)$ は無投薬の場合之变わ らなかった。それに対して，乳糖錠投与例の場 合， 2 週目上り予想外にその率が上昇し $(10 \%)$, 投薬終了後の消失率は $16 \%$ で，無投薬例のそれ より明らかに高かった。

乳糖錠が咽喉頭異常感に奏功するとは考光難 いので, 偶然得られた成績と思われる.しかし ながら，無投薬よりも，仮に偽薬であっても投 薬治療の方が高い効果を発揮する可能性はある.

\section{まとめ}

概して咽喉頭異常感症患者に汎用される薬剤 を大まかにグループ分けし，それらを単独使用 した際に咽喉頭異常感を消失させる効果がどの 程度あるかをみた。

それらの中では, 漢方製剤(半夏厚朴湯, 柴 胡加竜骨牡蠣湯, 柴朴湯) とスルピライドの効 果が優れていることが示唆された.

マイナートランキライザーの場合, 投薬終了 後の早期再然が問題であり，それを防ぐ意味で 投薬を止める際に何らかの工夫, 例えば, 消炎 ・鎮痛・解熱剤の併用投与などが必要と思われ 
た。

塩酸ドスレピンの様なほほぼ純粋な抗らつ成は 咽喉頭異常感症に対して無作意的に投与しても 大きい効果は期待できないようであった。

代謝性ホルモン剂は遅効性のようであり， 2 週間の投薬では十分な効果が発現しない可能性 があった。

消炎・鎮痛・解熱剂も効果の発現は遅く, 早 期により満足すべき効果を得ようとすれば，何 らかの薬剤, 例えば, マイナートランキライザー などを併用する必要があると思われた。

\section{参考文献}

1）小野真孝：咽 - 喉頭，食道異常感汇関する研究. 日耳鼻 $63: 778 \sim 793,1960$.

2）河合純一郎：下咽頭特殊異常感の発現機構に関 する研究. 日耳鼻 $64 ： 1058 \sim 1081,1961$.

3）大森一弘：咽喉頭食道異常感症の臨床的研究. 耳展 9 補 $1: 1 \sim 20,1966$.

4）山際幹和, 福生治城, 坂倉康夫, 他 : 半夏厚朴 湯による咽喉頭異常感症女性例の治療成績.耳 鼻臨床 $76: 1307 \sim 1319,1983$.

5）山際幹和, 福生治城, 坂倉康夫, 他 : 柴胡加竜 骨牡蠣湯による咽喉頭異常感症男性例の治療成 績. 耳鼻臨床 $76: 1517 \sim 1529,1983$.

6）山際幹和, 福生治城, 坂倉康夫, 他 : SERENAL (OXAZOLAM) に上る咽喉頭異常感症の治療成 績. 耳鼻臨床 $76: 2605 \sim 2613,1983$.

7）山際幹和, 福生治城, 坂倉康夫, 他 : 偽薬とし て用いた安中散による咽喉頭異常感症例の治療 成績. 耳鼻臨床 $76: 3041 \sim 3049,1983$.

8）山際幹和, 福生治城, 西岡博之, 他： Sulpiride 江よる咽喉頭異常感症の治療成績. 耳鼻臨床 $78: 1663 \sim 1673,1985$.

9）山際幹和, 福生治城, 久保将彦, 他 : 咽喉頭異 常感症中高年婦人例に対するメサルモン $\mathbb{B}-\mathrm{F}$ の効果. 耳鼻臨床 78：2017〜2029, 1985.

10）山際幹和, 原田輝彦, 久保将彦, 他 : 咽喉頭異 常感症に対する塩化リゾチームの効果. 耳鼻臨
床 $80: 999 \sim 1008,1987$.

11）山際幹和, 坂倉康夫, 久保将彦, 他 : 咽喉頭異 常感症に対する抗うつ剂 dosulepin hydrochloride の効果. 耳鼻臨床 $81 ： 297 \sim 307,1988$.

12）山際幹和, 久保将彦, 原田輝彦, 他 : 咽喉頭異 常感に対する消炎鎮痛剤の効果. 耳鼻臨床 82 ： 1497〜1506, 1989.

13）山際幹和，坂倉康夫，久保将彦，他：咽喉頭異 常感に対する Alprazolam の効果 一二重盲検 法に上る臨床的検討一. 耳鼻臨床 $83: 1285$ ～ 1297, 1990.

14）山際幹和, 原田輝彦, 坂倉康夫 : 柴朴湯を用い た咽喉頭異常感症の治療.耳鼻臨床 $84: 837$ 851, 1991.

15）山際幹和，福生治城，坂倉康夫，他：消炎剤々 鎮静剂による咽喉頭異常感症の治療成績.耳鼻 臨床 $76: 1685 \sim 1692,1983$.

16）山際幹和, 福生治城, 福喜多啓三, 他 : Mefenamic Acid と Oxazolam の併用による咽喉頭 異常感症の治療成績.耳鼻臨床 $77: 495 \sim 501$, 1984.

17）山際幹和, 福生治城, 坂倉康夫, 他 : 漢方薬と Minor Tranquilizer の併用による咽喉頭異常感 症の治療成績. 耳鼻臨床 $77: 2461 \sim 2472,1984$.

18）山際幹和, 福生治城, 久保将彦, 他 : 咽喉頭異 常感に対する Piroxicam の併用効果 一二重盲 験法による臨床的検討一。耳鼻臨床 $78: 1167$ $\sim 1180,1985$.

19）山際幹和, 久保将彦, 坂倉康夫, 他 : 咽喉頭異 常感症の薬物治療成績. 耳鼻臨床 $81: 1675$ $1684,1988$.

20）古江 尚, 原 義雄, 今村幸雄, 他：日本癌治 療学会固形がん化学療法直接効果判定基準. 日 癌治 $21 ： 929 \sim 942,1986$.

$$
\left.\begin{array}{l}
\text { 原稿受付 : 平成 } 3 \text { 年 } 8 \text { 月 } 26 \text { 日 } \\
\text { 原稿採択 : 平成 } 3 \text { 年 } 10 \text { 月 } 16 \text { 日 } \\
\text { 別刷請求先 : 山際幹和 } \\
\text { ₹514 津市江戸橋 } 2 \text { 丁目 } 174 \\
\text { 三重大学医学部耳鼻咽喉科学教室 }
\end{array}\right)
$$

